\title{
Sexualitet og imperialisme
}

Af Anna Rebecca Kledal

Seksualitet, køn og race har spillet en central rolle $i$ modet mellem europaere og ikke-europaere. I slutningen af 1800-tallet kom dette bl.a til udtryk i kolonimagternes konstruktion af "de andre", samt i forsøgene pai at reguleve racerelationen.

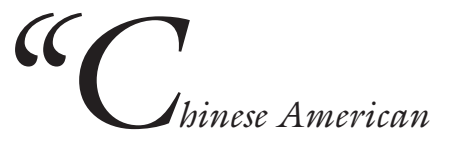

woman: another Jade Snow Wong Pocahontas yellow.".....Chinese American women sold out - are contemptuous of their culture, pathetically strain all their lives to be white, hate Asian American men, and so marry white men (the John Smiths) - or just like Pocahontas: we rescue white men while betraying our fathers; then marry white men, get baptized, and go to dear old England to become curiosities of the civilized world.

Merle Woo i “This Bridge Called my Back” (1981)

Disney koncernen lancerede for nogle år tilbage en rørende tegnefilm om den indianske Pocahontas, som redder den hvide John Smith fra at blive henrettet af de indfødte. I tegnefilmens morale påskyndes racerelationer mellem indfødte og europæere, og kærligheden mellem de forskellige racer sejrer derfor også til sidst. Rent historisk er "Pocahontas" ikke uproblematisk, og som ovenstående citat viser, har racerelationer 
igennem historien langt fra forløbet så fredeligt som hos Disney.

Det kan forekomme bemærkelsesværdigt, at netop mødet mellem europæere og ikke-europxere, og de deraf følgende blandinger/blandingskulturer, stadig ikke i den akademiske verden er genstand for analyse $\mathrm{i}$ nævneværdig grad. Det er i høj grad dette møde, denne artikel vil belyse. Artiklen handler om seksualitetens rolle i mødet mellem europæere og 'de andre, herunder focuseres på hvilke konstruktioner af køn dette medførte. Metodisk bygger artiklen på litterære værker, skrevet både af mænd og kvinder i den høj-imperiale periode, fremstillet enten som selvbiografi eller som fiktion. Det teoretiske grundlag bygger på post-koloniale diskursanalytiske bidrag, hvis grundlæggende opgør med den koloniale diskurs, lå i et opgør med en lang række forskellige videnskabelige discipliner - antropologi, kultursociologi, naturvidenskab, som påstod at referere en sand 'virkelighed', og hvis fremstillingen af virkeligheden fortalte 'sandheden' om eksempelvis andre lande, andre kulturer.

\section{DEKONSTRUKTION AF DEN}

\section{VESTEUROPÆISKE IMPERIALISME}

Ifølge den palæstinensisk fødte i USA-boende litterat Edward Said, er sådanne videnskabelige discipliner imidlertid diskursive konstruktioner. En given forfatter eller rejsebeskrivelse vil i sig selv være underlagt en historisk betinget diskurs. På den måde opfattes diskursen langt bredere, den henviser til alle slags tekster - både litterære og videnskabelige, som er blevet fremstillet om orienten. Postkoloniale teoretikere har påpeget, at vestlige forfattere især siden 1800tallet har konstrueret opfattelsen af 'orienten' som 'det andet', hvorved vesteuropæisk kultur kunne konstruere og producere orienten politisk, sociologisk, ideologisk, militært og videnskabeligt i den sene oplysningstid. ${ }^{1}$

I en analyse af mødet mellem europæere og indfødte bliver seksualiteten i de oversøiske kolonier et væsentligt fikspunkt, idet der på dette punkt findes en dokumenteret systematiseret styring - eller rettere; ønske om statslig styring med det formål at regulere racerelationerne. Menneskers hverdagsliv i kolonier er ikke specielt veldokumenteret. Anderledes forholder det sig imidlertid med seksualitet i eksempelvis de engelske kolonier. Soldaternes seksualitet blev institutionaliseret via de bordeller, som den engelske koloniale administration etablerede og var dermed under kontrol og styring. For de laverestående soldater, som var udstationerede, mente man fra den koloniale administrations side, at prostituerede var en nødvendighed. Prostitution hjalp de engelske soldater med at forblive mænd, både ved at styrke deres mandighed, samt afholde dem fra homoseksuelle relationer.

I forskningsbidrag fra tidligere slavesamfund som Caribien og Brasilien bliver der peget på historisk specifikke træk, som har haft betydning for de socio-økonomiske strukturer, der har formet relationer mellem mænd og kvinder, sorte og hvide, og de deraf følgende magtkonstellationer. Tereza Burmeister fremhæver således i en artikel fra 1996, at den sorte erotiserede kvindelighed - erotiseret af hvide og sorte mænd og kvinder - kom til at indgå som et grundlæggende element i udformningen af den nationale identitet.

Man kan her bruge Dorothy Smiths begreb "relations of ruling" $i$ en analyse af samspillet mellem kolonialismens konkrete historisk-politiske former og de seksualpolitiske erfaringer. 2 "Relations of ruling" kan som begreb betragtet identificere et kompleks af praksisser, som inkluderer regeringen, loven, økonomiske anliggender, såvel som fremstilling af tekster, alt dette som indgår i magtens mangeartede fora. Dette begreb giver mulighed for at dekonstruere den europxiske imperialisme og blotlægge de mange divergerende diskurser for at bryde med dikotomiske størrelser som 'de koloniserede' og 'kolonisatorerne'. Den histo- 
riske analyse kan på den måde kædes sammen med køn, klasse, race og seksualitetsaspekter, hvor både den europæiske vinkel, men også den såkaldte tredie verden kan analyseres. Det er ikke nok at fremstille undertrykkelsesformer som vesten mod resten, man må snarere analysere undertrykkelsesformer som noget, der kan forekomme på 'mangfoldige skuespladser', og hvor relationer mellem vestlige og ikke-vestlige mænd og vestlige og ikke-vestlige kvinder må sammentænkes med et seksualitets -og klasseaspektet. På denne måde bliver det muligt at anskue de mangfoldige og divergerende magtstruk-turer og måder, hvorpå magt eller styring udøves og indpodes.

\section{KØN OG RACE SOM \\ KATEGORISERINGSFAKTORER}

For at vende tilbage til Pocahontas er der stor forskel på racerelationernes udfoldelsesmuligheder $\mathrm{i}$ hendes tidsalder dvs. i slutningen af 1500-tallet, sammenlignet med den langt senere højimperiale tidsperiode. Perioden efter 1880'erne var karakteriseret ved systematisk mindreværdig behandling af 'de andre', til forskel fra perioden før 1870'erne, også kaldet 'transitions-perioden', hvor opfattelsen af de koloniserede stadig var genstand for videnskabelige diskussioner. 1880'erne var domineret af socialdarwinistiske tankesæt, hvor 'de andre' konsekvent bliver sammenlignet med børn, dyr etc. 'Race' var ikke kun den eneste 'naturlige kategoriseringsfaktor i opdelingen af mennesker. 'Køn' var ligeså vigtigt. I kategoriseringsprocessen indgik køn og race i forskellige kombinationer, således at afrikanere eksempelvis blev betegnet som "the lady of the races", og hvide kvinder blev sammenlignet med såkaldte 'svage' racer. Edward Said påpeger i "Orientalism Western concepts of the Orient" fra 1978:

\section{"De koloniserede subjekter blev anskuet som} andre elementer $i$ de vesteuropeiske samfund, for eksempel kriminelle, de sindssyge, kvinder eller fattige. Alle disse grupperinger havde en identitet som fremmede til falles. De koloniserede subjekter blev sjeldent set, de blev set igennem, de var genstand for analyse - ikke som medborgere men som problemer, der skulle fjernes eller loses."

Udgivelsen af "Orientalism" har de sidste 20 år til stadighed forårsaget en lang række debatter og kontroverser i den akademiske verden. Et sidste skud på stammen er Marianna Torgovnicks værk: "Primitive Passions. Men, Women and the Quest for Ecstasy" fra 1997. Saids konstante fokusering på Vesteuropas frastødelse og kategorisering af 'de andre mangler, ifølge Torgovnick, at inddrage den fascination af 'de andre', som kategoriseringen var ledsaget af. Torgovnick hævder ikke, at Vesteuropas negative holdninger og undertrykkelse af de koloniserede ikke fandt sted, men fremhæver, at kolonierne i ligesåhøj grad fremstod som eksotiske og erotiske steder, mænd og kvinder rejste hen for at forny sig; fornyelse både $\mathrm{i}$ form af klassemæssige opstigning og åndelig fornyelse.

\section{KONSTRUKTIONEN AF}

\section{DEN HVIDE MAND}

Det var ikke eksklusivt de indfødte kvinder og mænd, der var underlagt kategoriseringer. 'Hvide mænd' var ligeledes underlagt de konstruktioner og kategoriseringskomplekser, som medførte forskellige disciplineringsformer: Tale var underlagt bestemte normer, opførsel skulle følge bestemte kodex, selv følelser var underlagt bestemte ting og ikke andre. At være 'hvid mand', betød en helt bestemt måde at være tilstede i verden, en måde at forholde sig til virkeligheden, et bestemt sprog og tankesæt. Denne særlige tilstedeværelse i kolonierne var underlagt en del reguleringer. Der findes eksempler fra Indien, hvor udstationerede englændere ikke måtte være over 55 år, før de måtte afstå fra deres poster. Begrundelsen for dette var, at den indiske befolkning 
ikke måtte se hvide mænd som gamle, de skulle fremstå som raske, fyrige og rørige. 4 Også seksualiteten spillede en rolle for konstruktionen af den hvide mand. Den britiske kolonimagt sørgede for indfødte prostituerede til de menige britiske soldater, som var udstationeret i det engelske imperium. Den engelske klasseideologi slog igennem, idet det blandt officerer var yderst ilde set, at de blandede sig med den indfødte befolkning. At det var vigtigt for den hvide elite, at den forblev en elite overfor de koloniserede subjekter, var et grundlæggende element i datidens seksualitetsdiskurs.

Professor i tropemedicin, Leonore Manderson, gør i sine forskning om seksualitet og kolonialisme opmærksom på, at mænd blev opfattet som bærere af naturlige impulser og behov, behov som var heteroseksuelle. Men i mangel af kvinder kunne mænd have forhold til andre mænd. For at undgå sidstnævnte, blev prostitution en institutionel måde at håndtere den demografiske mangel på kvinder. 5 Prostitution blev - var argumenterne - en måde at holde unaturlige og abnorme seksuelle lyster fra døren. Prostitution var et nødvendigt onde for at undgå det, der var værre, nemlig homoseksualitet samt xgteskab med indfødte kvinder. Som en del af institutionaliseringen af prostitution medvirkede den koloniale administration $i$ at forbedre forholdene på bordeller, blandt andet for derved at undgå udbredelsen af kønssygdomme. ${ }^{6}$

\section{KONSTRUKTIONEN AF}

\section{DEN HVIDE KVINDE}

I den sen-victorianske periode begyndte kvinder i langt højere grad end før at rejse ud, både som led i en personlig, men også professionel frigørelse. Disse nye tendenser, som blandt andet udsprang af diskussionerne om 'den nye kvinde', betød dog langt fra, at alle de kvinder som rejste ud, også havde kvindepolitiske idealer.7 I diskussionerne om 'den nye kvinde udspillede der sig stor interesse for kvinders forandrede roller og livssituation, og 1890'erne var karakteriseret ved voksende kvindepolitiske ideer. Forbedringer af kvinders uddannelsesmuligheder, og de øgede muligheder for beskæftigelse, bevirkede for middelklasse kvinder, at det nu var muligt at vælge en karriere og et uafhængigt liv fremfor ægteskab og familieliv, som tidligere havde været så godt som de eneste muligheder for 'respektable kvinder'. Mange victorianske kvinder fandt derfor nye karrieremæssige muligheder i de oversøiske kolonier. ${ }^{8}$

Mange kvindesagsforkæmpere i datidens England opfordrede deres hvide medsøstre til at rejse ud til kolonierne for at hjælpe deres koloniserede søstre. Dette var ikke indskrevet i en anti-imperialistisk forståelsesramme, bag opfordringen lå tanker om den hvide civiliserede kvinde som bibringer af oplysning til indfødte kvinder. Det lå implicit $\mathrm{i}$ den hvide kvindes mission at rejse ud og hjælpe kvinder $\mathrm{i}$ andre kulturer til at få et bedre liv og dermed befri dem fra de kulturelt bundne tyrannier, de ansås for at leve under. Befrielsen lå i det imperialistiske projekt, som ville bringe civilisationen til andre folkeslag. ${ }^{9}$

Kvinder anså i langt mindre grad end deres mandlige kolleger sig selv for erobrere, men yndede snarere at fremstille sig selv som 'passive modtagere' af den kultur, de befandt sig i. ${ }^{10}$ Alligevel forsynede victorianske kvinder i lige så høj grad som deres hjemlige forskere den koloniale administration med data, vedrørende de indfødte, hvorved de i lige så høj grad bidrog til og var en del af imperiets selvforståelse.

I 1800-tallets kvindeideal, hvor kvinder pålagdes at være "the Angel of the House" samtidig med, at de var underkastet en lang række sociale, politiske og moralske restriktioner, blev opfattelsen af en 'respektable feminitet' produceret i sammenhæng med andre praksisser i samfundet. Den kvindlige seksualitet blev defineret $\mathrm{i}$ forhold til den mandlige, og blev opfattet som svag og passiv. ${ }^{11}$ Men samtidig blev den yderligere defineret i forhold til dikotomien: respektable/ 
faldne kvinder. Derfor fulgte angsten for kvinders ukontrollable seksualitet side om side med den victorianske opfattelse af kvindlighed, som baseret på opofrelse og renhed. Denne angst afspejlede sig i de overordnede praksisser vedrørende seksualitet i de oversøiske kolonier. Hvide kvinder skulle være bærere af den civilisatoriske mission, men skulle samtidig beskyttes (af hvide mænd) mod den ukontrollable seksualitet de hvide kvinders egen og 'the lustful natives'. Kontrollen over hvide kvinder måtte altså også håndhæves eftersom "The Angel of the House" potentielt var fulgt af skyggesiden - den faldne kvinde, den prostituerede.

\section{DE HVIDE KVINDERS}

\section{ROLLER I KOLONIERNE}

Historikere som Kenneth Ballhatchett har påpeget, at hvide kvinders tilstedeværelse $\mathrm{i}$ kolonierne uddybede skellet mellem den herskende elite og den indfødte befolkning. Da hvide kvinder kom til kolonierne, var det en af årsagerne til, at racerelationer forværredes, idet hvide mænd ikke længere kunne opretholde deres seksuelle forbindelser med deres indfødte elskerinder. ${ }^{12}$ Samtidig påtog de engelske kvinder sig rollerne som værtinder, og udbyggede de sociale samværdsformer og netværk blandt den hvide koloniale elite. Andre historikere som Vron Ware argumenterer derimod for, at hvide kvinder blev inddraget i de oversøiske kolonier som stabiliserende faktorer og derved blev en undskyldning for at opretholde en raceadskillelse. Feministen Sara Mills ${ }^{13}$ hævder derimod, at hvide kvinder formåede at gå imod den dominerende koloniale diskurs. Mandlige kolonisatorer differentierede ikke mellem de koloniserede, men så dem som en samlet homogen masse. Kvinder var derimod, mener Mills, i lagt højere grad opmærksomme på de etniske og kulturelle forskellighederne og i det hele taget 'andethed', fordi de selv var underlagt det mandlige blik. De kunne med andre ord ikke modsætte sig "the mastery of looking". Selvom
Mills pointe er interessant, findes der utallige eksempler på kvinders tilstedeværelse, medvirken og lige så racistiske attituder $\mathrm{i}$ imperiet, som deres mandlige modpart.

\section{KOLONIERNE SOM OASE FOR SEKSUELLE FANTASIER}

Kolonierne var ydermere steder, hvor hvide mænd og kvinder kunne rejse hen for at udleve deres seksuelle fantasier. Fantasier som ikke længere var mulige at udleve i Vesteuropa på grund af den institutionalisering og regulering, som seksualiteten var underlagt $\mathrm{i}$ de midt- og sen-victorianske samfund. Op gennem 1800-tallet blev seksualiteten således $\mathrm{i}$ stigende omfang viklet ind i et net af moralske, juridiske, politiske og økonomiske forpligtigelser, så kolonierne blev i denne sammenhæng det sted, hvor mænd kunne gøre sig andre seksuelle erfaringer end de, som kulturen i de vesteuropæiske samfund gjorde mulig. De fleste mandlige europæiske forfattere, der rejste ud, undlod ikke at beskrive disse seksuelle fantasier udlevet 'i det andet'. Derimod er kvindlige rejsebeskrivelser forbavsende tavse om dette emne. Vores hjemlige ikon, Karen Blixen, er en af de kvindelige forfattere, som er tavse omkring seksualiteten. Hun brød med sin danske småborgerlige familie og rejste til Afrika i perioden 1914-1931. I Kenya erfarede hun, at det var muligt at udleve sit kærlighedsliv og sexliv på en måde, som ikke var hende muligt hjemme i Danmark. Karen Blixen skrev aldrig om sex mellem europæere og afrikanere, men brugte det afrikanske scenario til at udleve sin egen seksualitet - blandt hvide mænd. I november 1923 påbegyndte hun et essay, som først langt senere, nemlig i 1977, blev udgivet under titlet: "Moderne ægteskab og andre betragtninger". Man må formode, at erfaringerne fra Kenya - xgteskabet med Bror Blixen, kærlighedsforholdet til Denys Finch-Hatton ansporede hende til et kønspolitisk og seksuelt opgør med konventionerne hjemme i det småborgerlige 


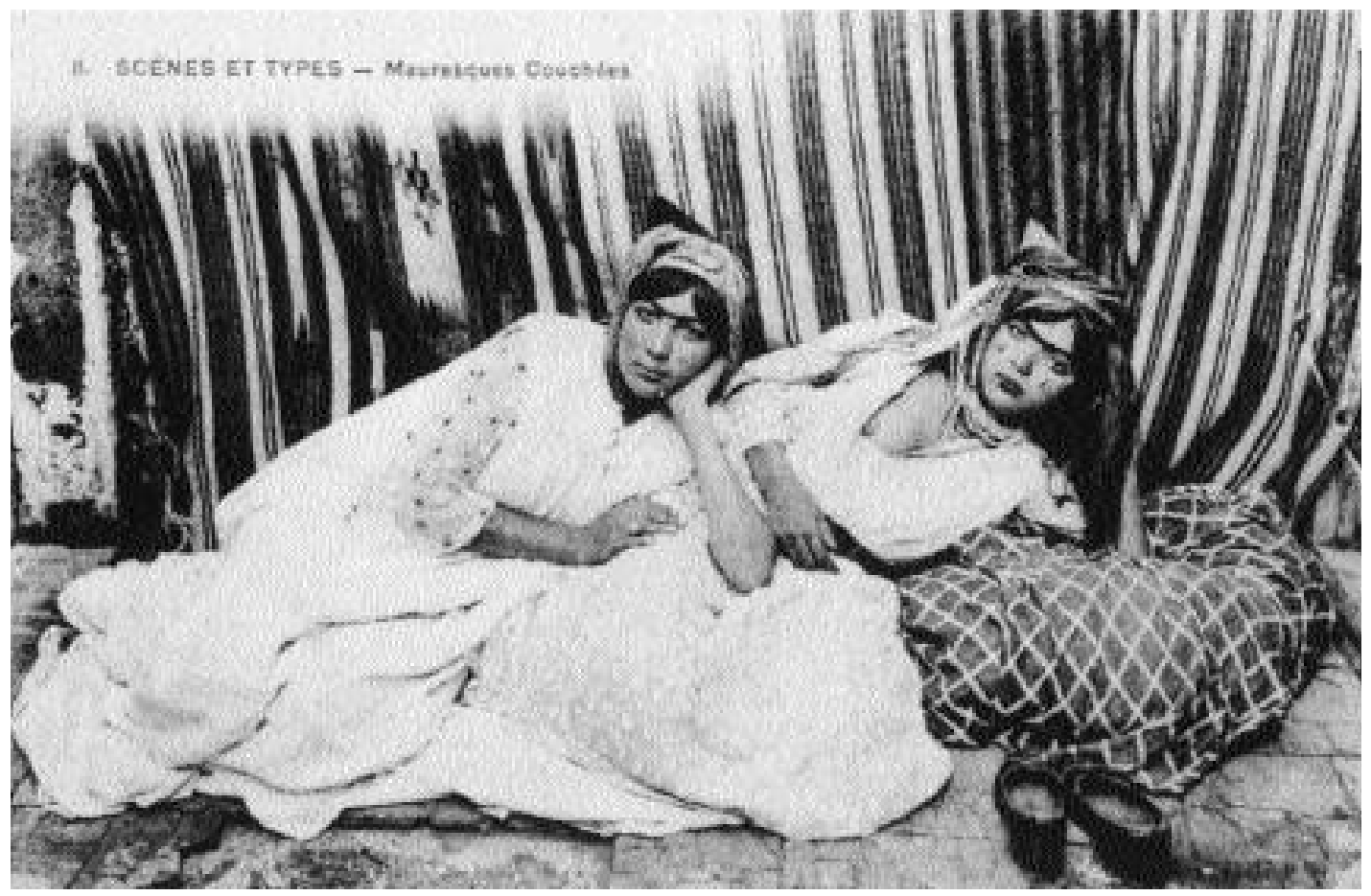

Postkort fra Algeriet. 
Danmark, for essayet indeholder problemstillinger og refleksioner, som afspejler hendes egen livssituation: den frie kærlighed overfor ægteskabet, og småborgerlige samfundsnormer overfor kærlighed og individets frihed. Nutidens holdning til rgteskabet som institution, beskriver Karen Blixen således:

\section{"At Indholdet er forteret, men Skallen kan holde sig oprejst, det er undertiden en Til- stand, som tilfredsstiller alle Parter..."14}

Selvom Karen Blixen forholdt sig til relationer mellem mænd og kvinder, xgteskab og den frie kærlighed, så er der ingen referencer til den afrikanske virkelighed. Det er en europæisk kvinde, som forholder sig til europæiske normer med europæiske referencerammer. Et eksempel, som til forskel fra Karen Blixen beskriver forholdet mellem europæere og ikke-europæere, kan findes i André Gides roman: "Hvis hvedekornet ikke dør" (1926). André Gide udlevede sin homoseksualitet i det nordlige Afrika og ekspliciterede sine homoseksuelle erfaringer i sine romaner. I romanen beskriver Gide en kærlighedsaffære med en ung algier:

\section{Min lyst var uden bagtanke og burde ikke} folges af nogen slags anger. Men hvad skal jeg sà kalde den henrykkelse, jeg folte ved at trykke denne lille fuldkomne krop, der var sky, lidenskabelig, ukysk og gåde fuld, ind til mit bryst?

Jeg befandt mig lenge, efter at Mohammed havde forladt mig, I en tilstand af jublende glade....." 5

Andre mandlige rejsebeskrivelser fra en tidligere periode, som kan nævnes, er Flaubert, Renan, Sir Richard Francis Burton. De var ligeledes fascineret af de arabiske kulturer og beskrev deres seksuelle fantasier - måske mere end deres faktiske forhold til arabiske kvinder. I deres romaner indgår haremmet som et centralt element i konstruktionen af den arabiske kvinde, som det eksotiske og erotiske andet. Det som den hvide europæiske kvinde ikke kunne og ikke skulle være.

\section{DEN EUROPÆISKE HAREMSFANTASI.}

Den vestlige opfattelse af haremmet indeholdt en opfattelse af orientens kvinder som adskilte/indelukkede fra den øvrige verden. Ifølge den vesteuropæiske konstruktion af haremmet, bestod den orientalske kvindes verden af intriger, jalousidramaer, hvis eneste betydningsfulde relationer med omverdenen var seksuelle relationer med mænd. Ellers forløb dagene i en endeløs strøm af stilhed, dovenskab, hvor deres eneste adspredelse bestod af herrebesøg. Stadig ifølge den europæiske opfattelse, var den orientalske kvindes eneste magtposition den seksuelle servicering eller forførelse af mænd.

På arabisk betyder ordet harim derimod enten 'helligt sted' eller 'kvindlige medlemmer af familien'.16 "Haram" eller "hurma" blev ligeledes i de arabiske samfunds øvre samfundslag brugt som respektfuld betegnelse for en gift kvinde, eller som betegnelse for et sted for kvinder i hjemmet. Graham-Brown gør opmærksom på, at den meget strenge adskillelse af kvinder og mænd hovedsageligt forekom i en lille, meget velhavende befolkningsgruppe, hvor kvinder ikke spillede en aktiv rolle i familiens økonomi, og derved kunne blive i hjemmet. Ydermere havde de fleste fattige familier i de arabiske lande ikke plads til den strenge kønsopdeling indenfor hjemmets fire vægge.

Hvorfor denne vesteuropæiske erotisering af den arabiske kvinde er forekommet, giver blandt andet den marokanske sociolog Fatima Mernissi et bud på. Hun mener ikke, at kønnenes adskillelse i islamiske kulturer bygger på opfattelsen af kvinder som biologisk mindreværdige, som det var tilfældet i datidens vesteuropæiske, victorianske diskurs. Snarere tværtimod, bygger hele adskillelsessystemet på opfattelsen af kvinder som stærke og farlige væsener - heri inkluderet, som bærere af farlige seksuelle liden- 
skaber. Kvinders seksualitet skal ledes ind $\mathrm{i}$ xgteskabet, og deres synlighed skal kontrolleres for at forhindre andre mænd $i$ at blive fristet. ${ }^{17}$ Det er haremmets utilgængelighed for vesteuropæiske mænd, ideen om haremmet som et sted for seksuelle udvekslinger og haremskvindernes udgangsforbud, der danner grundlag for den vesteuropæiske erotiseringen af arabiske kvinder.

Den algierske forsker Malek Alloula foretager i sit værk: "Le Harem Colonial: Images d un sous-érotisme" (1981), en diskursanalyse af koloniale postkort, som havde sin storhedstid fra århundredeskiftet til 1930. Disse postkort var i cirkulation og lettilgængelige blandt alle klasser i Europa. Også de fremstiller den algierske kvinde som det erotiske 'andet, altid halvt af-klædt, altid underlagt det koloniale blik. ${ }^{18}$ Den arabiske kvinde er haremmet. Alloula fremhæver, at netop det visuelle var en væ-sentlig faktor i grundfrestelsen af denne fantasi om den arabiske kvinde. Da vestlige fotografer sjældent kunne komme til at se og fotografere arabiske kvinder, var disse haremsscener konstruerede optagelser lavet i fotoatelier. Til forskel fra maleriet, som var tiltænkt at indeholde en stor dosis fantasi, blev fotografiet betragtet som virkelighedseksponerende og dermed mere troværdigt.

En kvinde, som fremstår interessant i forhold til visualisering af arabiske kvinder, er den polskfødte, dansk-gifte kunstmalerinde Elisabeth Jerichau-Baumann. Elisabeth Baumann rejste i perioden 18691870, samt i 1874-1875 til Nordafrika og Tyrkiet, og formåede på disse rejser at få adgang til haremmer og male de arabiske kvinder.Via sine portrætteringer fik hun personlige kontakter og relationer til kvinderne i haremmet, og hun var, ligesom sine vestlige landsmænd, grundlæggende fascineret af kvindernes erotiske udstråling, som er et gennemgående træk ved hendes portrætteringer. I sin bog "Brogede Rejsebillede" fra 1881, giver hun lange udførlige beskrivelser af livet i de tyrkiske haremmer. Men trods sine personlige relationer og sit inside kendskab undlod hun ikke at understrege den hvide kvindes overlegenhed over den arabiske. Ej heller, at arabiske kvinder levede i fangeskab i modsætning til civiliserede europæiske kvinder.

"At vegetere $i$ et rigtudstyret Harem, at gaa op I Nydelsen af det Materielle, at modtage sin Mand og Hersker - den eneste Afvexling I Haremslivets Monotoni - kan vare en almindeligt begavet, orientalsk opdraget Tyrkindes Lykke; men for den I Haremmet efter evropaisk Monster opdragede, fintdannede Prinsesse, der desuden ver begavet med uanmindelig Forstand og en Fantasi, der var bleven opflammet ved Digte og Romanlitteratur, var dette Liv I Haremmet undholdeligt; her var hun vel Herskerinde, og dog indesperret og sin Herres Slavinde, fattig paa Fribed og Livets sandeste Gleder, Livets egentlige Krav, skjønt omgivet af orientalsk Luxus. Hun blev under disse I Tyrkiet abnorme Forbold Civilisationens Matyrinde. "19

Elisabeth Baumanns holdninger til indfødte mænd, rummede ligeledes både fascination og fordømmelse. Dette er tydeliggjort i hendes beskrivelse af Shahen af Persien:

"Han var en agte Oriental med Tyrehals og merkelige blodtorstige mandelformede Øjne, der lignede en Nat, hvor det lyner. Han havde et Sanseligt og Grusomt udtryk, men Skjon var han dog!'20

I forhold til beskrivelser af livet i haremmet var Baumann en af de få kvinder, ${ }^{21}$ der både beskrev og malede forholdene i islamiske kulturer. Trods sin priviligerede adgang og inside kendskab indskrev hun sig alligevel i datidens europæiske diskurs om orientalske kvinder, mænd og deres livsformer.

\section{EPILOG}

De fleste europæere forholdt sig til de indfødte og europæere som to adskilte grupperinger. Vesteuropæiske kvinder og mænd, 


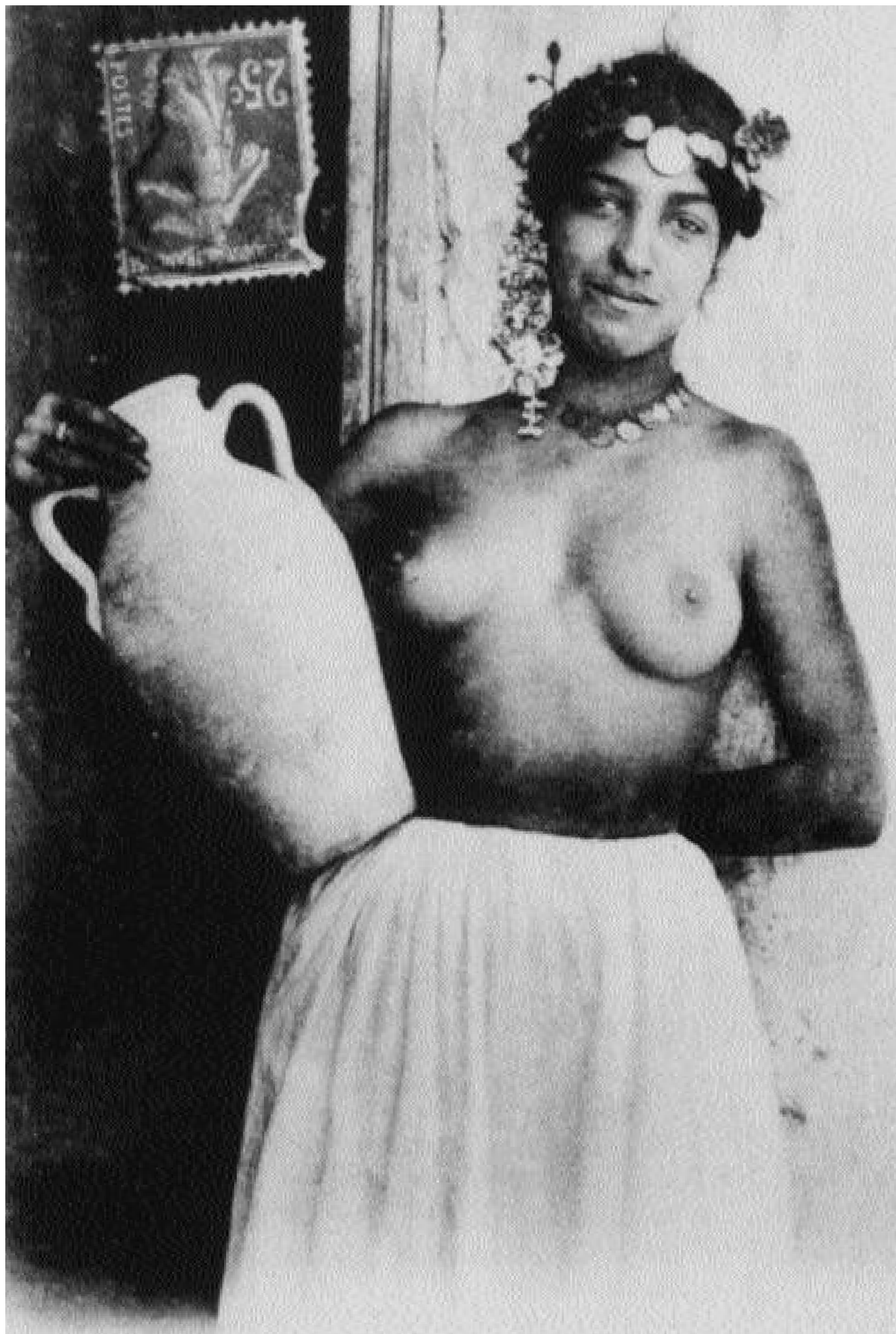

Algiersk postkort, af arabisk kvinde. 


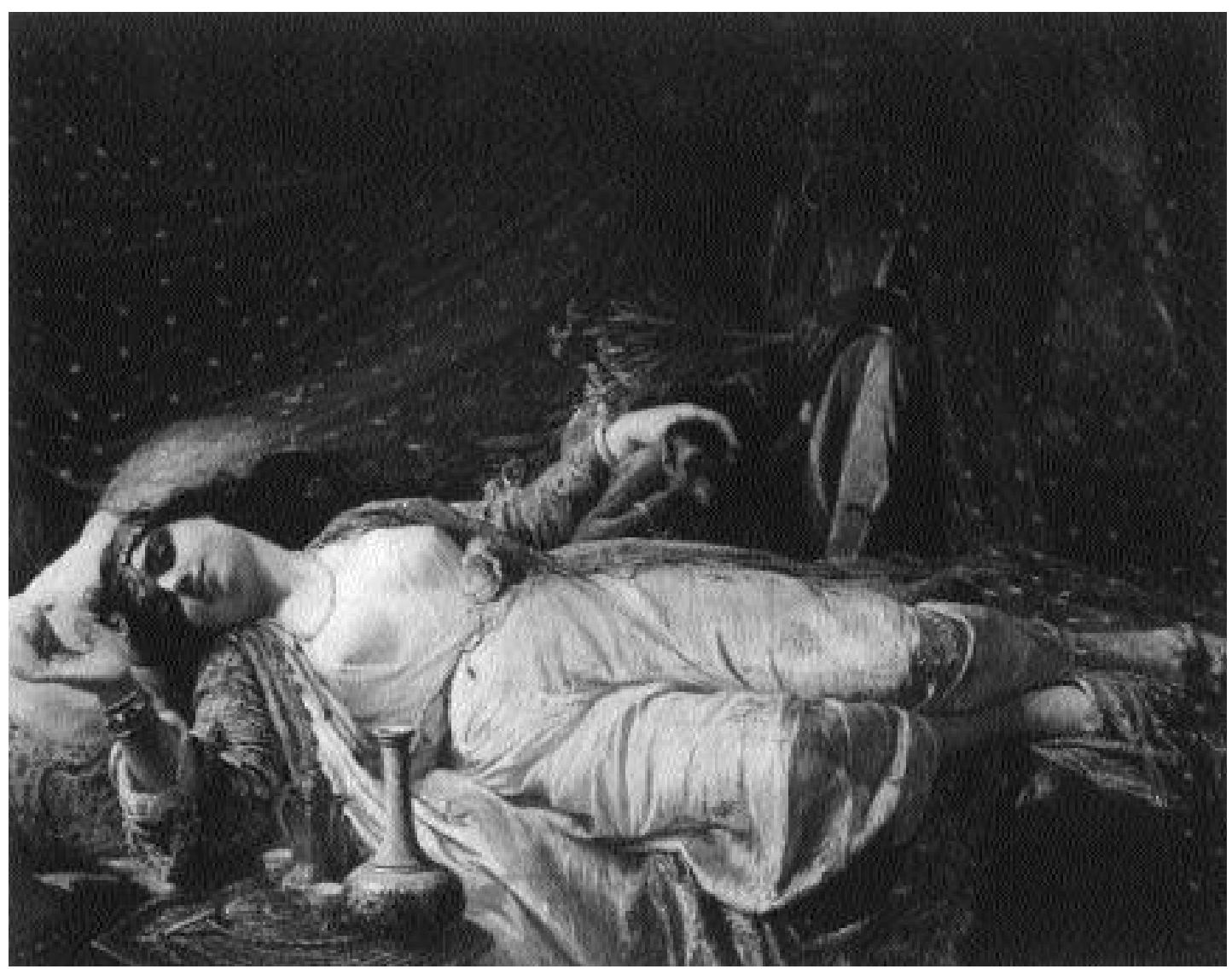

Malet af Elisabeth Jerichaw-Baumann, Prinsesse Nazili Hanum, 1875. 
som rejste ud, forholdt sig til indfødte, nogle differentierede mellem de forskellige kulturer og folkeslag, men grundlæggende var der ingen refleksioner over resultaterne af seksuelle/kærlighedsrelationer mellem europæere og ikke-europæere. Imperialismens paradox ligger i den konsolidering af blandingskulturer og blandede racer som kolonialiseringen og erobringerne medførte, samtidig med at denne sammenblanding - i den imperiale tankegang - betød undergang, og var synonym med døden. Kiplings roman "Beyond the Pale" fra 1888 er eksempelvis en kærlighedshistorie om en englænder bosat i Indien og en ung indisk kvinde. Kærlighedsforholdet opdages, og den indiske kvinde får skåret hænderne af og må bøde med livet. Kiplings morale på den tragiske kærlighedsaffære er herefter:

\section{"A man should, whatever happens, keep to his own caste, race and breed. Let the White go to the White and the Black to the Black.....He took too deep an interest in native life; but he will never do so again”. ${ }^{22}$}

Ligesom i Kiplings roman blev raceblandinger et symbol på og en trussel om, hvad en manglende adskillelse mellem den herskende engelske elite og de koloniserede subjekter kunne resultere i. Døden som resultat og den negative konnotation, som 'halfcastes' blev behæftet med, vedrører sammenhængen mellem seksualitet og kategorisering. 'Halfcastes var på kanten af det kendte og acceptable. De var udtryk for en destabilisering af den engelske seksualmoral, og de faldt udenfor de gxngse kategorier i det imperiale kategoriseringssystem ved hverken at være den ene eller den anden race. Som sådan truede de den magt og selvforståelse, som kategoriseringssystemet var et middel til både at legitimere og opretholde.

\section{Noter}

1. Said, Edward: "Orientalism-Western Concepts of the Orient" 1978 p.12).
2. Chandra Mohanty bruger Dorothy Smiths begreb 'relations of ruling'i Mohanty, Chandra: "Cartographies of Struggle", pp.1-47 i "Third World Women and the Politics of Feminism”. Indiana University Press, 1991.

3. Op.Cit Said, 1978 p.227

4. Op. cit Said, 1978 p.42

5. Manderson, Leonore: "Migration, prostitution and medical Surveillance in early 20th century Malaya". i Marks \& Worboys (eds): "Migrants, Minorities and Helayb: Historical and Contemporary Studies”. London Routledge, 1997, p.65

6. Manderson, Leonore: "Colonial desires: Sexuality, race and Gender in British Malaya" i "Journal of the History of Sexuality" 7, 3: 1997, p.377

7. Ware, Vron: "Moments of Danger: race, gender and memories of empire" $i$ "Feminists Revision $\mathrm{Hi}$ story". Verso, London 1994

8. Caine, Barbara: "Victorian Feminists". Oxford University Press, 1992.

9. Op. cit. Ware, Vron: 1994

10. Op. cit. Ware, 1994

11. Nead, Linda: "Myths of Sexuality. Representations of Women in Victorian Britain". Basil

Blackwell, London, 1988.

12. Ballhatchett, Kenneth: "Race, Sex and Class under the Raj: Imperial Attitudes and Policies and their Critics: 1793-1905". Weidenfeld \& Ni-

cholson, London, 1980. p. 119

13. Mills, Sara: "Discourses of Difference: An Analysis of Women's Travel Writing and Colonialism." Routledge, London, 1991.

14. Blixen, Karen: "Moderne ægteskab og andre betragtninger" i Blixeniana, København, 1977. p. 18

15. Gide, André: "Hvis hvedekornet ikke dør..." Hasselbalch, 1963 (1926) p.293

16. Graham-Brown, Sarah: "Images of Women ", 1988 p.71

17. Graham, Brown, Sarah: "Images of Women",1988 p. 72, og Bouhdiba, Abdelwahab. "Sexuality in Islam". Routledge og Kegan, London 1985 , p. 25

18. Bouhdiba gør opmærksom på blikkets betydning i Islam, hvor en væsentlig del af definitionen på at være muslim tilskrives blikket:

"To be a Muslim is to control one's gaze and to know how to protect one's own intimacy from that of others. However the concept of intimacy is farreaching, for we are confronted here by the concept of 'aura, which tradition divides into four categories: what man may see of woman, what a woman may see of a man, what a man may see of a man, what a woman may see of a woman". (Bouhdiba. p.37) 
19. Baumann-Jerichau, Elisabeth: "Brogede rejsebeskrivelser" Forlagsbureauet i Kjøbenhavn 1881. p.131

20. Op. cit. p. 44

21. Harriet Martineau aflagde to korte besøg til haremmer i Cairo og Damascus i 1840. Disse blev beskrevet med største afsky. Mere positivt skrev Lucy Gernett I 1890 om sine besøg i tyrkiske haremmer. (Graham-Brown. 1988, p. 78-79)

22. Kipling, Rudyard:"Beyond the Pale", 1888 p.5

\section{LITTERATUR}

- Alloula, Malek: "Le Harem Colonial: Images d un sous-érotisme." Editions Slatkine, Genève, Paris 1981.

- Anzaldua, Gloria (eds.): “This Bridge Called my Back. Writings by Radical Women of Color.” Kitchen Table: Women of Color Press. New York 1981.

- Ballhatchett, Kenneth: "Race, Sex and Class under the Raj: Imperial Attitudes and Policies and their Critics: 1793-1905". Weidenfeld \& Nicholson, London, 1980.

- Baumann-Jerichau, Elisabeth: "Brogede rejsebeskrivelser”. Forlagsbureauet i Kjøbenhavn 1881.

- Blixen, Karen: "Moderne ægteskab og andre betragtninger”, pp.7-61 i Blixeniana, København, 1977

• Bouhdiba, Abdelwahab. "Sexuality in Islam".

Routledge og Kegan, London 1985.

- Burmeister, Tereza: "Mae preta" og "neguinha". Etniske dimensioner i konstruktionen af kvindeligheden i det koloniale Brasilien i "Kvinder, Køn og Forskning” nr.4, 1996, p. 99-116.

. Caine, Barbara: "Victorian Feminists". Oxford

University Press, 1992.

. Gide, André: "Hvis hvedekornet ikke dør..."

Hasselbalch, 1963 (1926)

- Gilman, Sander: "Black Bodies, White Bodies: towards an iconography of female sexuality in the late nineteenth century art, medicine and literature" i Donald og Rattansi eds. : "Race, Culture and Difference". Sage, London, 1992.

- Graham-Brown, Sarah: "Images of Women: The portrayal of women in photography of the Middle East, 1860-1950.” London, Quartet, 1988.

. Kipling, Rudyard: "Beyond the Pale" (1888) i

"Stories and Poems", Methuen, London, 1970.

- Manderson, Leonore: "Migration, prostitution and medical Surveillance in early 20th century Malaya". i Marks \& Worboys (eds): "Migrants, Minorities and Health: Historical and Contemporary Studies". London Routledge, 1997, pp.49-69.

- Manderson, Leonore: "Colonial desires: Sexuali- ty, race and Gender in British Malaya" i "Journal of the History of Sexuality” 7, 3: 1997, pp372-388. - Mills, Sara: "Discourses of Difference: An Analysis of Women's Travel Writing and Colonialism." Routledge, London, 1991.

- Mohanty, Chandra: "Cartographies of Struggle" pp.1-47 I "Third World Women and the Politics of Feminism”. Indiana University Press, 1991.

- Nead, Linda: "Myths of Sexuality. Representations of Women in Victorian Britain". Basil Blackwell, London, 1988.

- Said, Edward: "Orientalism- Western concepts of the Orient". Penguin, London, 1978.

. Torgovnick, Marianna: "Primitive Passions. Men, Women and the Quest for Ecstasy." Alfred A. Knopf. New York 1997.

- Ware, Vron: "Moments of Danger: race, gender and memories of empire" i "Feminists Revision History”. Verso, London 1994

\section{SUMMARY}

The article deals with the construction of gender and sexuality in the colonial discourse. It is argued that sexuality is an important key to analysing relations between Europeans and non-Europeans, since sexuality was an area of institutionalisation by the imperial administration. By deconstructing Western European imperialism, it is possible to identify many different, emerging discourses and the complex dependency between Western Europeans and non-Europeans.

The Western European radicalised and genderized categorisation of "the other" and "otherness" was followed by the fascination of "the other". "Otherness" was the constant mirror for Western European self-reflection. Likewise, the sexualised "other" was a reflection of the construction of sexuality in the late-Victorian Western European societies. The colonies came to function as an oasis for Western erotic and exotic fantasies, and in the Oriental discourse the harem became the place in poetry, novels and painting for Western European male and female construction of the sexualised "other".

Anna Rebecca Kledal, Cand.mag. i historie/Internationale udviklingsstudier

Ph.D.-stipendiat ved Institut for Historie og Samfundsforhold, Roskilde Universitetscenter 